\title{
Symposium on 'Nutrition in the post-genomic era' Plenary session 4: Genetic variation and diet-related disease
}

\section{Gene polymorphisms, inflammatory diseases and cancer}

\author{
W. Martin Howell ${ }^{1 *}$, Philip C. Calder and Robert F. Grimble ${ }^{2}$ \\ ${ }^{1}$ Histocompatibility \& Immunogenetics Laboratory/Human Genetics Division, \\ Southampton University Hospitals, Southampton SO16 6YD, UK \\ ${ }^{2}$ Institute of Human Nutrition, University of Southampton, Southampton SO16 7PX, UK
}

\begin{abstract}
Genes whose products play a critical role in regulation of the immune response include the human leucocyte antigen (HLA) and cytokine families of genes. The HLA genes are the most polymorphic found in the human genome, and the bulk of this polymorphism results in functional differences in expressed HLA molecules, resulting in inter-individual differences in presentation of peptide antigens to T-cells. In addition, a considerable number of cytokine-associated gene polymorphisms have been identified, the bulk of which occur in the upstream promoter sequences of these genes, which in many cases results in differential in vitro expression of the respective proor anti-inflammatory gene product. Particular HLA polymorphisms result in well-defined associations with a large number of immunologically-mediated diseases, including some diseases with known dietary risk factors. For example, individuals of HLA-DQA1*0501, DQB $1 * 0201$ genotype have a greater than 200-fold increased risk of developing intolerance to dietary wheat gluten (coeliac disease), and additional HLA-related factors may influence the development of malignant lymphoma within pre-existing coeliac disease. Similarly, HLA-DRB1 alleles sharing a common sequence motif constitute the primary known genetic risk factor for rheumatoid arthritis. The influence of polymorphisms associated with differential cytokine expression on disease susceptibility is currently of much interest. Most attention has been focused on associations with susceptibility to benign immunologically-mediated diseases, including a number of gut diseases. However, recent work from our laboratory indicates that cytokine polymorphisms may influence susceptibility to and prognosis in a number of different cancers, including malignant melanoma skin cancer and solid tumours which may be influenced by diet, such as prostate cancer (collaboration with the CRC/BPG UK Familial Prostate Cancer study). In addition, preliminary work suggests that dietary modulation of expression levels of certain cytokines in healthy human subjects may be genotype dependent.
\end{abstract}

\section{Résumé}

Parmi les gènes dont les produits jouent un rôle critique dans la régulation de la réponse immune, on trouve les familles de gènes de l'antigène leucocyte humain (ALH) et de la cytokine. Les gènes ALH sont les plus polymorphes du génome humain, et ce polymorphisme entraîne des différences fonctionnelles des molécules ALH exprimées, qui se traduit par des différences individuelles dans la manière dont des peptides antigéniques se présentent aux cellules $\mathrm{T}$. De plus, un nombre considérable de polymorphismes des gènes associés a la cytokine ont été identifiés, la plupart d'entre eux se produisent au niveau du promoteur de ces gènes, ce que dans de nombreux cas se traduit par l'expression différentielle in vitro de leurs respectifs produits génétiques pro- ou antiinflammatoire. Des polymorphismes ALH particuliers aboutirent à des associations bien définies avec un grand nombre de maladies immunologiquement mediées, parmi lesquelles quelques-unes

\footnotetext{
Abbreviations: CMM, cutaneous malignant melanoma; HLA, human leucocyte antigen; IL, interleukin; LT, lymphotoxin; PC, prostate cancer; PCR, polymerase chain reaction; RA, rheumatoid arthritis; RFLP, restriction fragment length polymorphism; SNP, single nucleotide polymorphism; SSOP, sequence-specific oligonucleotide probe; TNF, tumour necrosis factor.

*Corresponding author: Dr W. M. Howell, fax +44 238070 1416, email wmh1@ soton.ac.uk
} 
avec des facteurs de risque diététique. Par exemple, des individus de génotype HLA-DQA $1 * 0501$, DQB $1 * 0201$ ont un risque deux cent fois plus grand de développer une intolérance au gluten alimentaire (maladie céliaque), et des facteurs additionnels en relation avec l'ALH peuvent influencer le développement d'un lymphome maligne dans une maladie céliaque existante. De même, des allèles HLA-DRB1 qui partage une séquence motive commune constituent le premier facteur de risque génétique de l'arthrite rhumatoïde. L'influence de polymorphismes associés a une expression de cytokine différentiel sur la susceptibilité aux maladies présent dans ce moment un grand intérêt. La plupart de l'attention a était centré les associations avec la susceptibilité de maladies mediées immunologiquement bénignes, parmi eux un grand nombre de maladies de l'intestin. Toutefois, un travail récent dans notre laboratoire indique que les polymorphismes de la cytokine peuvent influencer la susceptibilité à certains cancers (ainsi que son pronostic), entre eux le mélanome de peau maligne et des tumeurs solides qui peuvent être affectés par l'alimentation, comme le cancer de prostate (collaboration avec le CRC/BPG étude familial du cancer de prostate Royaume-Uni). De plus, des travails préliminaires suggèrent que la modulation par l'alimentation des niveaux d'expression de certaines cytokines dans des sujets humains peut être dépendent du génotype.

Gene polymorphisms: Inflammatory diseases: Cancer: Human leucocyte antigen genes: Cytokine genes

Presentation of processed antigenic peptide to T-cell receptor molecules expressed on T-cells by cell-surface human leucocyte antigen (HLA) molecules is the critical initiating event in the T-cell immune response. In the presence of appropriate co-stimulatory molecules, responding T-cells secrete a range of soluble cytokine mediators, which act to regulate both T- and B-cell immune responses, as well as acting on other cellular components of the immune response, such as macrophages and natural killer cells. In the present article, the function, extent and identification of naturallyoccurring polymorphisms of the HLA loci will be reviewed, and the role of HLA polymorphism in predisposition to immune-mediated diseases will be considered. Coeliac disease and rheumatoid arthritis (RA) will be considered as exemplars, since the HLA associations concerned are particularly well described and both diseases have dietary risk factors. Immunogenetic evidence linking development of enteropathic lymphoma with coeliac disease will also be presented. Polymorphism in coding sequences of T-cell receptor genes is much more limited in extent (Kay, 1996) and will not be reviewed here.

In addition, an increasing number of polymorphisms associated with differential production of cytokine gene expression in vitro has been described, many of which show associations with susceptibility to a number of immunemediated diseases. The nature of these polymorphisms and their laboratory identification will be summarised. Recent work from a number of laboratories, including our own, suggests that certain of these polymorphisms are associated with susceptibility to and/or prognosis in a number of cancers. These cancers may include those with dietary links, such as prostate cancer (PC). Finally, evidence has been obtained indicating that dietary modulation of expression levels of certain cytokines in healthy human subjects may be genotype dependent.

\section{Human leucocyte antigen molecules and gene polymorphisms}

Cell-surface HLA molecules function to present processed antigenic peptide, held within a groove in the HLA molecule, to $\mathrm{T}$-cell receptor molecules expressed on the surface of T-cells. HLA class I A, B and C molecules present intracellularly processed peptides (eight to ten amino acids in length), largely derived from endogenous antigens (both self and viral antigens), to CD8+ T-cells, the majority of which are of cytotoxic phenotype. HLA class II DR, DQ and DP molecules present processed peptides (fourteen to twenty-five amino acids in length), largely derived from exogenous antigens, to CD4+ T-cells, which are mainly of 'helper' phenotype. While HLA class I molecules are expressed on virtually all nucleated cells and platelets, HLA class II expression is more limited, being restricted to B-cells, professional antigen-presenting cells and activated $\mathrm{T}$ lymphocytes, but is also interferon- $\gamma$ inducible, and up-regulated HLA class II expression is often observed in inflammatory and autoimmune diseases.

The genes encoding the HLA molecules, within the major histocompatibility complex (chromosome 6p21.3), are the most polymorphic within the human genome, with at least 225 HLA-A, 444 HLA-B, 111 HLA-C 2 DRA, 350 DRB, 22 DQA1, 47 DQB1, 20 DPA1 and 96 DPB1 alleles currently recognised (Robinson et al. 2001). The antigen-binding groove of class I molecules is encoded by exons 2 and 3 of the gene, while the class II antigen-binding groove is encoded by exon 2 of the respective A and B genes for that subregion of the major histocompatibility complex. The vast majority of coding polymorphisms is contained within these exons. In addition, polymorphism is clustered within a limited number of hypervariable regions within each exon (e.g. typically six hypervariable regions for exon 2 of an HLA class II gene such as DPB1). Polymorphic differences 
in the hypervariable regions of these exons are rarely allelespecific. Rather, hypervariable sequence motifs are often shared between a number of alleles, and so a unique allele sequence is composed of a unique combination of sequence motifs at these hypervariable regions. The situation with respect to HLA class I genes is more complex, not only because polymorphism is spread over two exons, but because sequence motifs at the hypervariable regions are not only shared between different alleles of the same locus, but also can be shared between alleles of more than one class I gene or pseudogene.

The overwhelming majority of HLA polymorphisms result in functional amino acid substitutions in the expressed HLA molecules, with the bulk of these functional substitutions occurring with the peptide-binding grooves of the molecules. This process results in expressed HLA molecules encoded by different alleles exhibiting different peptidebinding specificities. In this way, genetic polymorphism within the HLA-encoding genes can modulate the immune response to a vast range of antigens, with inter-individual differences in immune responses to complex or simple antigens resulting from differing efficiencies of peptide binding to particular expressed HLA molecules. Due to this exuberant HLA polymorphism and its central role in the immune response, characterisation of this polymorphism within the HLA genes and encoded molecules is of critical importance in the clinical laboratory in both bone marrow and solid organ transplant patient-donor matching and in HLA-disease association studies (Bidwell \& Navarrete, 2000). In our laboratory, characterisation of HLA polymorphism has also provided a tool for determination of individual identity during the investigation of potentiallycontaminated or mislabelled surgical biopsy specimens (Bateman et al. 1994, 1996, 1997, 1999).

\section{Molecular identification of human leucocyte antigen polymorphisms}

Early methods for HLA typing were based on the detection of expressed HLA molecules on the surface of separated T-cells (HLA class I products) and B-cells (HLA class II products) using panels of antisera, usually obtained from multiparous women in a complement-dependent cytotoxicity test (Mittal et al. 1968). This technique has limited powers of resolution, especially for HLA class II alleles, and is dependent on isolation of live lymphocytes from the individuals to be genotyped.

For the past decade, DNA-based methods have been the principal tools for HLA typing in both research and clinical laboratories. The first comprehensive DNA-based HLA class II DR/DQ typing system was based on restriction fragment length polymorphism (RFLP; Bidwell et al. 1988). DNA-RFLP typing has now been almost entirely superseded by the more rapid polymerase chain reaction (PCR)based DNA-amplification methods. When combined with initial PCR amplification of the gene or exon in question, restriction enzyme cutting sites can be identified within PCR amplicons (PCR-RFLP; for example, see Uryu et al. 1990). The principle of the widely-used PCR-sequencespecific oligonucleotide probe (SSOP) typing approach is that individual alleles or allele groups can be discriminated by hybridization of immobilized PCR product containing the hypervariable regions to be typed with appropriately labelled SSOP (Krausa \& Browning, 1996). PCR-sequencespecific primer methods are based on the specificity of a PCR being dependent on precise matching of the terminal $3^{\prime}$ end of a PCR primer and its target DNA sequence (Olerup \& Zetterquist, 1992). PCR-sequence-specific conformation polymorphism relies on single-stranded form PCR products containing different sequence polymorphisms that will adopt different conformations and will therefore differ in mobility in electrophoresis (Blasczyk et al. 1995). Heteroduplex analysis is another conformation-based technique that relies on the formation of mismatched heteroduplexes between closely similar but non-identical complementary DNA strands during PCR. This approach has recently been developed into a reliable method for allelic-level HLA typing, termed reference-strand-mediated conformation analysis (Arguello et al. 1998).

Despite their tremendous utility, PCR-SSOP and PCRsequence-specific primer-based methods can only test for known HLA polymorphisms, although aberrant typing results may provide preliminary evidence for potential new alleles (Hemmatpour et al. 1998). Direct DNA sequencing is needed to identify and characterize such alleles (Ross, 2000). A more detailed review of DNA-based HLA typing methods is given by Howell \& Poole (2002).

\section{Human leucocyte antigen polymorphism and disease predisposition}

Due to the critical role of the HLA system in regulating the immune response, combined with the extensive polymorphism of both HLA class I and class II genes, it is perhaps unsurprising that particular HLA polymorphisms have been linked to susceptibility to a large number of immunologically-mediated diseases, including skin, gut, endocrine and joint diseases (for reviews, see Thorsby, 1997; Lechler \& Warrens, 2000). A non-exhaustive

Table 1. Human leucocyte antigen (HLA)-associated non-neoplastic diseases

\begin{tabular}{lll}
\hline Disease & Associated HLA allele & Relative risk* \\
\hline Ankylosing spondylitis & B27 & $>150$ \\
Reiter's disease & B27 & $>40$ \\
Anterior uveritis & B27 & $>20$ \\
Narcolepsy & DQ6 & $>38$ \\
Grave's disease & DR3 & 4 \\
Myasthenia gravis & DR3 & 2 \\
Addison's disease & DR3 & 5 \\
Rheumatoid arthritis & DR4 & 9 \\
Juvenile rheumatoid arthritis & DR8 & 8 \\
Coeliac disease † & DQ2 & 250 \\
Multiple sclerosis & DR2, DQ6 & 12 \\
Type I diabetes mellitus $\neq$ & DQ8 & 14 \\
& DQ6 & 0.02 \\
\hline
\end{tabular}

*The relative risk is a measure of how much more frequently the disease in question occurs in individuals possessing the particular HLA allele, compared with those not carrying the allele.

tThe most common HLA association with coeliac disease is with the DQA1 ${ }^{\star} 0501$, DQB1 *0201 alleles.

$\ddagger$ Complex HLA associations exist with type I diabetes mellitus. 
summary is given in Table 1. Some HLA-disease associations occur with only a single or related group of HLA alleles within a particular HLA gene (e.g. ankylosing spondylitis and molecular subtypes of the HLA-B27 group of alleles; Sorrentino \& Tosi, 1997), while others are rather complex (e.g. type 1 diabetes mellitus which is associated with a certain combination of the HLA-DQB1 alleles inherited either on the same or on different chromosomes; Nepom, 2000). These associations are believed to occur due to inter-individual differences in the efficiency of presentation of antigens important in the disease pathogenesis, to T-cells.

The link between HLA genetic polymorphism and the precise three-dimensional structure and peptide-binding specificity of the antigen-binding groove of the encoded HLA molecules suggests that it should be possible to determine the antigen, or derived antigenic peptide, associated with the aberrant immune response that may represent a key event in the development of the disease in question. Despite this link, the antigens that may be responsible for initiating autoimmune and other HLA-associated inflammatory diseases are not known for the majority of diseases. In only a minority of diseases have the molecular mechanisms underlying the HLA-disease association been elucidated. A comprehensive overview of HLA and disease associations will not be given here, since excellent overviews occur elsewhere (for example, for a detailed overview, see Lechler \& Warrens, 2000; for brief reviews, see Thorsby, 1997; Klein \& Sato, 2000). However, two of the best-described examples comprise diseases with known dietary risk factors, i.e. coeliac disease and RA, and these two examples will be considered later. In addition, we believe that HLA polymorphism may also act as a risk factor for the development of enteropathy-associated T-cell lymphoma within coeliac disease, suggesting that HLA polymorphisms can, directly or indirectly, influence the development of neoplastic disease within pre-existing benign conditions.

\section{Human leucocyte antigen, coeliac disease and enteropathy-associated T-cell lymphoma}

Coeliac disease is a malabsorptive disorder of the small intestine which is precipitated by ingestion of wheat gluten and related proteins from other cereals (principally barley, rye and possibly oats). The mucosal lesions are characterized by villous atrophy, hyperplastic crypts and T-cell infiltration in the lamina propria. The disease has long been thought to result from an abnormal immune response to gluten, initiated by activation of T-cells in the lamina propria to gluten-derived peptides (Scott et al. 1997). In addition, HLA-associated predisposition to coeliac disease is very strong, with DQA1*0501, DQB1*0201 genotypes conferring a relative risk of approximately 250-fold (Sollid $\&$ Thorsby, 1993). Elegant experiments have subsequently shown that the pathological intestinal $\mathrm{T}$ lymphocyte response to the $\alpha$-gliadin component of gluten in adult coeliac disease is focused on two immunodominant DQA1*0501, DQB1*0201-restricted peptides that overlap by a seven-residue fragment of gliadin. These peptides contain a glutamic acid residue (produced by the action of tissue transglutaminase on native antigen) which is critical for HLA-DQA $1 * 0501$, DQB $1 * 0201$ binding and Tcell recognition. These peptides cannot bind to HLA-DQ molecules expressed by individuals of other HLA-DQ genotypes, who are therefore tolerant of gluten in their diet (Arentz-Hansen et al. 2000).

HLA associations with neoplastic diseases may provide additional evidence for a pathogenic relationship between these conditions and non-neoplastic conditions from which they may arise. In the context of coeliac disease and enteropathy-associated T-cell lymphoma (a high-grade T-cell non-Hodgkin's lymphoma), we have shown that the DQA $1 * 0501$, DQB $1 * 0201$ alleles are also increased in frequency among patients with enteropathy-associated T-cell lymphoma, suggesting that the two conditions are genetically related (Howell et al. 1995). Furthermore, patients with uncomplicated coeliac disease, particularly of early onset, show an increased frequency of DQB $1 * 0201$ homozygosity compared with those with enteropathyassociated T-cell lymphoma. These results suggest that among individuals who possess the HLA-DQA1*0501, DQB1*0201 genotype, HLA-DQB1*0201 homozygosity predisposes to early-onset more-severe disease, which is more likely to be diagnosed and the patient placed on a gluten-free diet. Conversely, individuals possessing the HLA-DQA $1 * 0501$, DQB1*0201 genotype in the absence of DQB1*0201 homozygosity have a delayed clinical presentation, resulting in a longer period of subclinical disease, and therefore an extended period of gluten-derived antigen stimulation, with an increased risk of emergence of a neoplastic T-cell population (Howell et al. 1995).

\section{Human leucocyte antigen and other gastrointestinal diseases}

While the HLA-DQA1, DQB1 association with coeliac disease is the strongest and most clear-cut HLA-disease association, HLA associations with other gastrointestinal diseases have also been reported, but findings are variable, with respect to both ulcerative colitis and Crohn's disease. Relative risks, both predisposing and protective, are generally weak. Several studies have reported a slight increase in HLA-DRB $1 * 15$ alleles in patients with ulcerative colitis, and there are also several reports of a reduced frequency of HLA-DRB $1 * 04$, which may be associated with more extensive disease (for review, see Sollid et al. 2000). Conversely, there are few reports of significant HLA associations in Crohn's disease, and most studies conclude that this disease is not HLA-associated (for example, see Bouma et al. 1997).

\section{Human leucocyte antigen and rheumatoid arthritis}

RA is one of the most important autoimmune disorders, with a worldwide distribution and a prevalence in Caucasoid populations of approximately $1 \%$. The underlying pathogenesis of the disease in multifactorial, with both genetic and environmental factors, which may include diet, playing important roles. Considerable evidence points to the importance of the immune system in joint destruction and 
systemic disease (Fox, 1997), with T-cell responses important in at least the disease initiation process.

Multiple genes are likely to be involved in susceptibility to RA. However, the principal known locus contributing to disease susceptibility is HLA-DRB1. Several HLA-DRB1 alleles contribute to RA susceptibility, but each of these alleles (DRB1*0401, 0404, 0405, 0101, 1402) contains identical nucleotide sequences (except DRB $1 * 0401$, which is near-identical) encoding amino acids $67-74$ of the expressed DR $\beta 1$ chain. This so-called 'shared epitope' hypothesis accounts for HLA associations with RA in various ethnic groups: DRB $1 * 0401,0404$ and 0101 in Caucasoid populations, DRB1*0405 in Asians and DRB1*1402 in native Americans (Ollier \& Thomson, 1992). In addition, most studies which stratify patients with RA according to disease severity indicate that the DRB1*04-associated susceptibility alleles (DRB1*0401, 0404 and 0405) are associated with more severe forms of erosive disease (Nepom et al. 1996). The amino acids comprising the 'shared epitope' form two of the pockets in the peptide-binding cleft of the expressed HLA-DR molecule, and therefore may favour binding and presentation of certain 'arthritogenic' peptides, which have yet to be identified. Alternatively, the susceptibility-conferring HLA-DR molecules contain an amino acid sequence that also occurs in glycoprotein B of the Epstein-Barr virus and of the heat-shock protein DnaJ of Escherichia coli. Thus, it is possible that infections with these organisms may lead to the development of antibodies that recognise these self HLA molecules. This mechanism of induction of autoimmune disease has been termed 'molecular mimicry' (Baum et al. 1996).

\section{Human leucocyte antigen polymorphisms and cancer}

Several studies have indicated that the HLA gene complex may mediate susceptibility to a number of haematological malignancies, including Hodgkin's disease (Bodmer et al. 1992) and childhood common acute lymphoblastic leukaemia (Taylor et al. 1998), although the HLA-associated relative risks are modest (Table 2).

Table 2. Human leucocyte antigen (HLA)-associated neoplastic diseases (for review, see Bateman \& Howell, 1999)

\begin{tabular}{ll}
\hline Disease & Associated HLA allele \\
\hline Hodgkin's disease* & DPB1 ${ }^{*} 0301$, DPB1 ${ }^{*} 0401$, \\
& DPB1 ${ }^{*} 0901$ \\
Acute lymphoblastic leukaemia & DPB1 *02, DPB1 *05 \\
Cervical intraepithelial neoplasia & DQB1 *03, DQB1 *0602 \\
Cervical squamous cell carcinoma & DQB1 *0301, 0303, 0602 \\
Kaposi's sarcoma & DR5 \\
Burkitt's lymphoma & A1, B12, DR7 \\
Colo-rectal carcinoma† & DQB1 *0301 \\
EATL & DQB1 ${ }^{*} 03, \mathrm{DQA} 1{ }^{*} 0501,0201$ \\
Cutaneous malignant melanoma & DQB1 *0301, 0303
\end{tabular}

EATL, enteropathy-associated T-cell lymphoma.

${ }^{*}$ DPB $1{ }^{*} 0401$ is associated with a protective effect for Hodgkin's disease in

Orientals, while DPB1 ${ }^{*} 0901$ is associated with a shorter duration of

disease remission in Japanese patients.

†DQB1 *0301 may be associated with less-advanced tumours.
HLA associations with non-lymphoreticular malignancies have also been reported, including cervical cancer, and both melanoma and non-melanoma skin cancers (Bateman et al. 1998; Bateman \& Howell, 1999). In such cases, the precise role of tumour-associated inflammatory cell infiltrates is unclear and any such association is likely to be complex. For example, an inflammatory cell infiltrate may represent an immune response against the tumour, resulting in a better disease prognosis, as seen in cutaneous malignant melanoma (Clark et al. 1989). Alternatively, inflammatory cells may promote or inhibit tumour growth via secondary effects on other molecular processes such as angiogenesis (Leek et al. 1996). The latter hypothesis provides a potential link between HLA molecules and cytokines in the control of the immune response in both inflammatory and neoplastic diseases.

\section{Cytokine polymorphisms and the immune response}

Cytokines are generally small molecules secreted by one cell to alter the behaviour of itself or another cell, generally within the haematopoietic system. Cytokines act on target cells by binding to specific receptor ligands, initiating signal transduction and second messenger pathways within the target cell. Cytokines function as players in a highlycomplex coordinated network in which they induce or repress their own synthesis as well as that of other cytokines and cytokine receptors. This complexity is compounded by the fact that there is often considerable overlap and redundancy between the functions of individual cytokines. Production of numerous cytokines by the cells of the immune system, in response to both antigen-specific and non-specific stimuli, plays a critical role in the generation of both pro- and anti-inflammatory immune responses. For example, cytokines such as tumour necrosis factor (TNF) $\alpha$ (encoded within the major histocompatibility complex at chromosome 6p21.3) and interleukin (IL)1 (chromosome $2 q 14)$ are usually regarded as key pro-inflammatory cytokines, while cytokines such as IL-10 (chromosome 1q31-32) are anti-inflammatory, with strong immunosuppressive properties.

A considerable body of research undertaken in recent years (for review, see Bidwell et al. 1999) has shown that polymorphisms occur in the upstream regulatory ('promoter') regions of many cytokine genes, which may be functionally relevant in that these polymorphisms may influence the level of expression of these genes. Many studies support this hypothesis for several cytokine genes, e.g. TNF- $\alpha$ (Allen, 1999), IL-10 (Turner et al. 1997b), although in vivo the situation is almost certainly more complex, and genotype $v$. expression correlations may be influenced both by stimulus and cell type (Kroeger et al. 2000). Due to the documented role of up-regulation or dysregulation of expression of key pro- and anti-inflammatory cytokines in inflammatory lesions and in a large number of autoimmune diseases and malignancies, there has been considerable interest in determining whether the cytokine genetic profile of an individual results in qualitative or quantitative programming of his or her inflammatory response. This factor may result in cytokine gene polymorphisms mediating predisposition to particular immunologically- 
mediated diseases, or influencing their clinical course. Accordingly, development of robust molecular genotyping techniques for identifying known and novel cytokine polymorphisms is crucial for research in this area.

\section{Molecular identification of cytokine polymorphisms}

Unlike HLA polymorphisms, which consist of multiple polymorphic sites within a single gene, with clusters of hypervariable sequence motifs resulting in multiple expressed alleles, most cytokine coding and non-coding coding sequence polymorphisms are single nucleotide polymorphisms (SNP), usually bi-allelic in nature. Despite this fundamental difference, many of the methods used to type for HLA polymorphisms can also be used to type for cytokine SNP. Screening for novel cytokine promoter SNP is often undertaken using the PCR-sequence-specific conformation polymorphism approach (for example, see Fishman et al. 1998), with subsequent confirmation by DNA sequencing. Genotyping for known polymorphisms can then be performed by a number of approaches, principally PCR-RFLP, PCR-SSOP and amplification refractory mutation system-PCR, the latter being synonymous with PCR- sequence-specific primer methodology.

Certain cytokine SNP lead to substitutions in the recognition sites of particular restriction endonucleases e.g. the TNF- $\beta$ (lymphotoxin (LT)- $\alpha$ ) +252 intron polymorphism results in two alleles, the DNA of one allele being sensitive to digestion by the Nco I restriction enzyme, while DNA from the second allele is not (Messer et al. 1991). Polymorphisms such as these are detectable by the PCRRFLP approach. Further examples of such polymorphisms are TNF- $\alpha-308$ (BsmF I) and IL-6 -174 (Nco I). Numerous other cytokine SNP correspond to restriction endonuclease cutting sites (for review, see Bidwell et al. 1999).

In principle, all cytokine SNP are detectable using PCRSSOP, using separate oligonucleotide probes for each SNP (Perrey et al. 1998). Amplification refractory mutation system-PCR approaches have also been developed for numerous cytokine SNP, an area in which our laboratory has a special interest (Howell et al. 2001, 2002b; Poole et al. 2001). While standard amplification refractory mutation system-PCR techniques for bi-allelic SNP utilise two PCR per SNP, i.e. one for each allele, it is possible to modify the methodology such that both alleles are typable in a single PCR, using the so-called 'tetraprimer approach' (Karhukorpi \& Karttunen, 2001; Ye et al. 2001).

\section{Cytokine polymorphisms and immune-mediated diseases}

In recent years a considerable effort has been expended by numerous laboratories in order to determine whether cytokine promoter polymorphisms (and indeed other coding and non-coding polymorphisms associated with differential cytokine expression in vitro) contribute to susceptibility to, or influence clinical course in, a number of immunemediated diseases and in clinical transplantation. A fairly upto-date summary is provided by Bidwell et al. (1999). For example, claimed associations between TNF- $\alpha-238,-308$ and -376 promoter polymorphisms and RA (Brinkman et al.
1997), cerebral malaria (Knight et al. 1999), asthma (Moffatt \& Cookson, 1997) and cardiac and renal transplant rejection (Turner et al. 1997a; Sankaran et al. 1998) have been reported. Likewise, associations between IL-10 promoter polymorphisms and systemic lupus erythematosus (Lazarus et al. 1997), RA (Hajeer et al. 1998) and asthma (Lim et al. 1998) have been described. Other cytokine polymorphisms, including IL-2-related polymorphisms, have been implicated in susceptibility to RA (John et al. 1998). However, there is still some conflict in the published literature in this field. For example, studies from our own and other laboratories do not show a significant association between recipient TNF- $\alpha$ genotype and renal transplant rejection, possibly due to differing patient selection criteria and/or immunosuppressive drugs used (Marshall et al. 2000; Poole et al. 2001).

\section{Cytokine polymorphisms and cancer}

A number of studies have reported associations between TNF- $\alpha$ and/or LT $\alpha$ polymorphisms and particular cancers, including chronic lymphocytic leukaemia (Demeter et al. 1997) non-Hodgkin's lymphoma and breast cancer (Chouchane et al. 1997). In our laboratory we are investigating whether cytokine polymorphisms influence susceptibility to and/or prognosis in cutaneous malignant melanoma (CMM), since there is strong evidence for anti-tumour immune responses in CMM: early (radial growth phase) CMM tumours are characteristically associated with a T-cell infiltrate; the prognosis of more advanced and potentially metastasising (vertical growth phase) tumours is influenced by the extent of T-cell infiltration, while such T-cells have been shown to recognise melanoma antigen-derived peptides in an HLA-restricted fashion (Le Drean et al. 1995). These findings have been supported by variable HLA associations with susceptibility to, and prognostic markers in, CMM (for example, see Bateman et al. 1998). Elevated expression of IL-10 (a potent immunosuppressive cytokine) has been implicated in inhibition of the anti-tumour T-cell immune response in CMM, leading to tumour escape (for example, see Dummer et al. 1995). Conversely, other studies have described IL-10associated anti-tumour activities in CMM, with IL-10 acting to inhibit angiogenesis and hence tumour growth (Huang et al. 1999). Work from our group has supported an antitumour effect of IL-10 in CMM, with genotypes associated with low IL-10 expression in vitro associated with disease susceptibility and with markers of more advanced, poorer prognosis disease (higher stage, vertical growth phase, thicker primary tumours), while 'high expression' genotypes are protective (Howell et al. 2001). Thus, IL-10 genotype is associated with both susceptibility to, and prognostic indicators in, CMM. This outcome may be mediated by high levels of IL-10 inhibiting expression of vascular endothelial growth factor (chromosome $6 \mathrm{p} 12$ ), a potent mediator of tumour angiogenesis. In support of this possible mechanism, further studies in our laboratory have indicated that vascular endothelial growth factor-promoter genotypes, associated with lower vascular endothelial growth factor expression, are associated with markers of less-advanced better disease prognosis (lower stage, thinner primary tumours; Howell et al. 2002a). Conversely, we have failed to demonstrate any associations between TNF- $\alpha$ and/or 
LT $\alpha$ polymorphisms and CMM susceptibility or prognosis (Howell et al. 2002b).

Dietary factors have been reported to influence the development of numerous cancers, including a number in which immune responses to tumour may also be important. In this context, $\mathrm{PC}$ is of particular interest, since it is an ideal target for dietary chemoprevention, due to its long latency, high incidence, tumour marker availability and identifiable preneoplastic lesions and high-risk groups. There is also considerable evidence that diets rich in fibre and soyabean protein and low in animal fats are protective in PC development (for review, see Schulman et al. 2001). Other vitamins, especially vitamin $\mathrm{E}$, minerals and trace elements such as $\mathrm{Zn}$, Se and isoflavanoids are also implicated in prostate tumour inhibition (Schulman et al. 2001). Identification of genotypically 'at risk' individuals could further tailor this approach. Linkage studies have mapped several PC-susceptibility loci, but as yet no genes have been identified with certainty. However, there is now accumulating evidence that anti-tumour immune responses can occur in PC, as suggested by the isolation of prostate-infiltrating T-cells from normal tissue and PC lesions, responsive to prostate-specific antigens (Vesalainen et al. 1994). Dysregulation of cytokine expression in patients with PC has also been reported, both systemically and within tumours (for example, see Culig et al. 1998). A preliminary analysis of cytokine-promoter polymorphisms in our laboratory suggests that, in agreement with findings for CMM, genotypes associated with low IL-10 and high vascular endothelial growth factor production in vitro are risk factors for PC (McCarron et al. 2002). These genotypes may act to promote tumour angiogenesis, as we have hypothesised for CMM.

\section{Diet-genotype interactions in modulating the immune response}

Considerable evidence now exists that both diet (Calder, 2001) and genotype can modulate immune function, but as yet there have been virtually no studies of whether diet and genotype interact in modulating the immune response in health and disease. In our laboratory, as proof of principle, we are investigating whether diet and genotype show interactive effects on TNF- $\alpha$ production by peripheral blood mononuclear cells in healthy subjects.

In the immune response TNF- $\alpha$ expression is induced rapidly following infection and injury, with widespread effects, including stimulus of a diverse range of immunomodulatory cytokines and oxidant molecules (Grimble, 1996), creating a hostile environment for invading pathogens. However, excessive or untimely TNF- $\alpha$ production plays a major part in mortality and morbidity from sepsis (van der Poll \& van Deventer, 1999), meningitis (Westendorp et al. 1997) and malaria (Knight \& Kwiatowski, 1999). TNF- $\alpha$ also plays an important part in the pathology of inflammatory diseases such as RA (Maini \& Taylor, 2000) and inflammatory bowel disease (Murch et al. 1991), in the development of atherosclerotic plaques (Ross, 1993) and in rejection of transplanted tissues (Kutukculer et al. 1995). While expression of TNF- $\alpha$ is normally constant in healthy males and post-menopausal females (Jacob et al. 1990), as reviewed earlier, polymorphisms in both the TNF- $\alpha$ and LT $\alpha$ genes are associated with differential TNF- $\alpha$ and LT $\alpha$ expression in vitro. Furthermore, these polymorphisms show associations with susceptibility to a number of inflammatory and neoplastic diseases.

Fish oil, which is rich in $n-3$ polyunsaturated fatty acids has been shown to exert an anti-inflammatory influence in a number of animal models of inflammation and produces anti-inflammatory effects in RA (Kremer, 2000), Crohn's disease (Belluzzi et al. 1996) and psoriasis (Mayser et al. 1998). Fish oil may therefore provide a means of treating inflammatory disease in addition to standard drug therapy. Several (but not all) studies have also shown that dietary supplementation with fish oil reduces production of TNF- $\alpha$ by peripheral blood mononuclear cells, but with high levels of intra-individual variation in response to fish oil (for example, see Caughey et al. 1996). In order to clarify our understanding of the ability of fish oil to variably reduce expression of TNF- $\alpha$, we have investigated ex vivo TNF- $\alpha$ production by peripheral blood mononuclear cells stimulated with lipopolysaccharide, before and after a 3-month period of fish oil supplementation in healthy males, and related TNF- $\alpha$ production to polymorphisms in the TNF- $\alpha$ and LT $\alpha$ genes of the subjects. Preliminary results indicate a complex interaction between dietary fish oil supplementation and genotype. First, differing sensitivities of the subjects to dietary supplementation with fish oil were observed, with individuals showing high inherent production of TNF- $\alpha$ being more sensitive to the antiinflammatory effects of fish oil (Grimble et al. 2002). Second, medium and high inherent TNF- $\alpha$ production was associated with homozygosity for the LT $\alpha+252$ (TNFB)2 allele. Third, individuals with medium or low levels of TNF$\alpha$ production were more likely to experience the antiinflammatory effects of fish oil if they were heterozygous for the LT $\alpha+252$ (TNFB) alleles (Grimble et al. 2002). While the molecular mechanisms underlying this dietgenotype interaction in modulating TNF- $\alpha$ production remain uncertain, our results do suggest that investigation of the precise nature of both genetic and non-genetic determinants will enable fish oil supplementation to be used in influencing inflammation with greater precision than is currently the case. This concept could be extended to understanding the relationship between the availability of certain nutrients and the responsiveness of individuals to those nutrients with respect to predisposing to health or disease.

\section{Concluding remarks}

Immune response genes exhibit extensive polymorphism. In the case of HLA genes, the bulk of this polymorphism is functional and influences antigenic peptide presentation to T-cells, a critical step in initiation of T-cell responses to antigen. HLA polymorphism is implicated in conferring genetic susceptibility to a large number of immunemediated diseases, including some cancers. Similarly, single nucleotide polymorphisms have been identified in the promoter regions of a number of cytokine genes, which may influence expression of these genes in vitro and perhaps in vivo. A considerable body of data indicates that particular cytokine polymorphisms, especially those 
involving TNF- $\alpha$ and IL-10 genes, may influence susceptibility to, and in some cases prognosis in, both benign and neoplastic diseases. Very preliminary evidence suggests that cytokine genotype may interact with dietary factors in modulating pro-inflammatory immune responses.

\section{References}

Allen RD (1999) Polymorphism of the human TNF- $\alpha$ promoter random variation or functional diversity? Molecular Immunology 36, 1017-1027.

Arentz-Hansen H, Korner R, Molberg O, Quartsen H, Vader W, Kooy YMC, Lundin KEA, Koning F, Roepstorff P, Sollid LM \& McAdam SN (2000) The intestinal T cell response to $\alpha$-gliadin in adult celiac disease is focused on a single deamidated glutamine targeted by tissue transglutaminase. Journal of Experimental Medicine 191, 603-612.

Arguello JR, Little A-M, Bohan E, Goldman J, Marsh SG \& Madrigal JA (1998) High resolution HLA class I typing by Reference Strand Mediated Conformation Analysis (RSCA). Tissue Antigens 52, 57-66.

Bateman AC, Hemmatpour SK, Theaker JM \& Howell WM (1997) Nested polymerase chain reaction-based HLA class II typing for the unique identification of formalin-fixed and paraffinembedded tissue. Journal of Pathology 181, 228-234.

Bateman AC \& Howell WM (1999) Human leukocyte antigens and cancer: is it in our genes? Journal of Pathology 188, 231-236.

Bateman AC, Leung ST, Howell WM, Roche WR, Jones DB \& Theaker JM (1994) Detection of specimen contamination in routine histopathology by HLA class II typing using the polymerase chain reaction and sequence specific oligonucleotide probing. Journal of Pathology 173, 243-248.

Bateman AC, Sage DA, Al-Talib RK, Theaker JM, Jones DB \& Howell WM (1996) Investigation of specimen mislabelling in paraffin-embedded tissue using a rapid, allele-specific, PCR-based HLA class II typing method. Histopathology 28, 169-174.

Bateman AC, Turner SJ, Theaker JM \& Howell WM (1998) HLA-DQB $1 * 0303$ and $* 0301$ alleles influence susceptibility to and prognosis in cutaneous malignant melanoma in the British caucasian population. Tissue Antigens 52, 67-73.

Bateman AC, Turner SJ, Theaker JM, Warren BF \& Howell WM (1999) Polymerase chain reaction-based human leukocyte antigen genotyping for the investigation of suspected gastrointestinal biopsy contamination. Gut 45, 259-263.

Baum H, Davies H \& Peakman M (1996) Molecular mimicry in the MHC: hidden clues to autoimmunity? Immunology Today $\mathbf{1 7}$ 64-70.

Belluzzi A, Brignola C, Campieri M, Pera A, Boschi S \& Miglioli M (1996) Effect of an enteric coated fish oil preparation on relapses in Crohn's disease. New England Journal of Medicine 334, 1557-1616.

Bidwell J, Keen L, Gallagher G, Kimberly R, Huinzinga T, McDermott MF, Oksenberg J, McNicholl J, Pociot F, Hardt C \& D'Alfonso S (1999) Cytokine gene polymorphism in human disease: on-line databases. Genes and Immunity 1, 3-19.

Bidwell J \& Navarrete C (2000) Histocompatibility Testing. London: Imperial College Press.

Bidwell JL, Bidwell EA, Savage DA, Middleton D, Klouda PT \& Bradley BA (1988) A DNA-RFLP typing system that positively identifies serologically well-defined and ill-defined HLA-DR and DQ alleles, including DRw10. Transplantation 45, 640-646.

Blasczyk R, Hahn U, Wehling J, Huhn D \& Salama A (1995) Complete subtyping of the HLA-A locus by sequencespecific amplification followed by direct sequencing or single- strand conformation polymorphism analysis. Tissue Antigens $\mathbf{4 6}$ $86-95$.

Bodmer JG, Tonks S, Oza AM, Mikata A, Takenouchi T, Lister TA \& collaborating centres (1992) Hodgkin's disease study. In HLA 1991, vol. 1, pp. 701-709 [K Tsuji, M Aizawa and T Sasazuki, editors]. Oxford: Oxford University Press.

Bouma G, Oudkerk Pool M, Crusius JB, Schreuder GM, Hellemans HP, Meijer BU, Kostense PJ, Giphart MJ, Meuwissen SG \& Pena AS (1997) Evidence for genetic heterogeneity in inflammatory bowel disease (IBD); HLA genes in the predisposition to suffer from ulcerative colitis (UC) and Crohn's disease (CD). Clinical and Experimental Immunology 109, 175-179.

Brinkman BM, Huizinga TW, Kurban SS, van der Velde EA, Schreuder GM, Hazes JM, Breeveld FC \& Verweij CL (1997) Tumour necrosis factor alpha gene polymorphisms in rheumatoid arthritis: association with susceptibility to, or severity of, disease? British Journal of Rheumatology 36, 516-521.

Calder PC (2001) Polyunsaturated fatty acids, inflammation and immunity. Lipids 36, 1007-1024.

Caughey GE, Mantzioris E, Gibson RA, Cleland LG \& James MJ (1996) The effect on human tumor necrosis factor alpha and interleukin 1 beta production of diets enriched in $n-3$ fatty acids from vegetable oil or fish oil. American Journal of Clinical Nutrition 63, 116-122.

Chouchane L, Ben Ahmed S, Baccouche S \& Remadi S (1997) Polymorphism in the tumour necrosis factor- $\alpha$ promotor region and in the heat shock protein 70 genes associated with malignant tumours. Cancer 80, 1489-1496.

Clark WH Jr, Elder DE, Guerry D IV, Braitman LE, Trock BJ, Schultz D, Synnestvedt M \& Halpern AC (1989) Model predicting survival in stage I melanoma based on tumour progression. Journal of the National Cancer Institute 81, 1893-1904.

Culig Z, Hobisch A, Herold M, Hittmair A, Thurnher M, Eder IE, Cronauer MV, Rieser C, Ramoner R, Bartsch G, Klocker H \& Konwalinka G (1998) Interleukin 1beta mediates the modulatory effects of monocytes on $\mathrm{LNCaP}$ human prostate cancer cells. British Journal of Cancer 78, 1004-1011.

Demeter J, Porzsolt F, Ramisch S, Schmidt D, Schmid M \& Messer G (1997) Polymorphism of the tumour necrosis factor-alpha and lymphotoxin-alpha genes in chronic lymphocytic leukaemia. British Journal of Haematology 97, 107-112.

Dummer W, Becker JC, Schwaaf A, Leverkus M, Moll T \& Brocker EB (1995) Elevated serum levels of interleukin-10 in patients with metastatic malignant melanoma. Melanoma Research 5, 67-68.

Fishman D, Faulds G, Jeffery R, Mohamed-Ali V, Yudkin JS, Humphries S \& Woo P (1998) The effect of novel polymorphisms in the interleukin-6 (IL-6) gene on IL-6 transcription and plasma IL-6 levels, and an association with systemic-onset juvenile chronic arthritis. Journal of Clinical Investigation 102, 1369-1376.

Fox DA (1997) The role of T cells in the immunopathogenesis of rheumatoid arthritis: new perspectives. Arthritis and Rheumatism 40, 598-609.

Grimble R, Calder P, Howell W, O'Reilly G, Hirrell S, Turner S, Markovic O \& East M (2002) Associations between polymorphisms in the lymphotoxin- $\alpha$ (LT- $\alpha)$ and tumour necrosis factor- $\alpha$ (TNF- $\alpha)$ genes and the ability of fish oil to suppress TNF- $\alpha$ production by peripheral blood mononuclear cells (PBMC) in healthy men. American Journal of Clinical Nutrition 76, 454-459.

Grimble RF (1996) Interaction between nutrients, pro-inflammatory cytokines and inflammation. Clinical Science 91, 121130.

Hajeer AH, Lazarus M, Turner D, Mageed RA, Vencovsky J, Sinnott PJ, Hutchinson IV \& Ollier WE (1998) IL-10 gene 
promoter polymorphisms in rheumatoid arthritis. Scandinavian Journal of Rheumatology 27, 142-145.

Hemmatpour SK, Dunn PPJ, Evans PR, Green A \& Howell WM (1998) Functional characterization and exon 2-intron 2-exon 3 gene sequence of HLA-B*2712 as found in a British family. European Journal of Immunogenetics 25, 395-402.

Howell WM, Bateman AC, Turner SJ, Collins A \& Theaker JM (2002a) Influence of vascular endothelial growth factor single nucleotide polymorphisms on tumour development in cutaneous malignant melanoma. Genes and Immunity 3, 229-232.

Howell WM, Leung ST, Jones DB, Nakshabendi I, Hall MA, Lanchbury JS, Ciclitira PJ \& Wright DH (1995) HLA-DRB, DQA and DQB polymorphism in celiac disease and enteropathyassociated $\mathrm{T}$ cell lymphoma: common features and additional risk factors for malignancy. Human Immunology 43, 29-37.

Howell WM, \& Poole KL (2002) The special case of HLA genes: detection and resolution of multiple polymorphic sites within a single gene. In Molecular Genetic Epidemiology - A Laboratory Perspective, pp. 131-152. [INM Day, editor]. Heidelberg: Springer.

Howell WM, Turner SJ, Bateman AC \& Theaker JM (2001) Il-10 promoter polymorphisms influence tumour development in cutaneous malignant melanoma. Genes and Immunity 2, 25-31.

Howell WM, Turner SJ, Collins A, Bateman AC \& Theaker JM (2002b) Influence of TNF $\alpha$ and LT $\alpha$ single nucleotide polymorphisms on susceptibility to and prognosis in cutaneous malignant melanoma in the British population. European Journal of Immunogenetics 29, 17-23.

Huang S, Ullrich SE \& Bar-Eli M (1999) Regulation of tumour growth and metastasis by interleukin-10: the melanoma experience. Journal of Interferon and Cytokine Research 19, 697-703.

Jacob CO, Franek Z, Lewis GD, Koo M, Hansen JA \& McDevitt HO (1990) Heritable major histocompatibility complex class IIassociated differences in production of tumor necrosis factor- $\alpha$ : relevance to genetic predisposition to systemic lupus erythematosus. Proceedings of the National Academy of Sciences USA 87, 1233-1237.

John S, Myerscough A, Marlow A, Hajeer A, Silman A, Ollier W \& Worthington J (1998) Linkage of cytokine genes to rheumatoid arthritis. Evidence of genetic heterogeneity. Annals of the Rheumatic Diseases 57, 361-365.

Karhukorpi J \& Karttunen R (2001) Genotyping interleukin-10 high and low producers with single-tube bi-directional allele-specific amplification. Experimental and Clinical Immunogenetics 18, 67-70.

Kay RA (1996) TCR gene polymorphisms and autoimmune disease. European Journal of Immunogenetics 23, 161-177.

Klein J \& Sato A (2000) The HLA system. Second of two parts. New England Journal of Medicine 343, 782-786.

Knight JC \& Kwiatowski D (1999) Inherited variability of tumor necrosis factor production and susceptibility to infectious disease. Proceedings of the Association of American Physicians 111, 290-298.

Knight JC, Udalova I, Hill AVS, Greenwood BM, Peshu N, Marsh K \& Kwiatowski D (1999) A polymorphism that affects OCT-1 binding to the TNF promoter region is associated with severe malaria. Nature Genetics 22, 145-150.

Krausa P \& Browning M (1996) Detection of HLA gene polymorphism. In HLA and MHC: Genes, Molecules and Function, pp. 113-137 [M Browning and A McMichael, editors]. Oxford: BIOS Scientific Publishers Ltd.

Kremer JM (2000) n-3 fatty acid supplements in rheumatoid arthritis. American Journal of Clinical Nutrition 71, 3495-3515.

Kroeger KM, Steer JH, Joyce DA \& Abraham LJ (2000) Effects of stimulus and cell type on the expression of the -308 tumour necrosis factor promoter polymorphism. Cytokine 12, $110-119$.

Kutukculer N, Shenton BK, Clark K, Rigg KM, Forsythe JL, Kirby JA, Proud G \& Taylor RM (1995) Renal allograft rejection: temporal relationship and predictive value of plasma TNF (alpha and beta), IFN-gamma and soluble ICAM-1. Transplant International 8, 45-50.

Lazarus M, Hajeer AH, Turner D, Sinnott P, Worthington J, Ollier WE \& Hutchinson IV (1997) Genetic variation in the interleukin 10 gene promoter and systemic lupus erythematosus. Journal of Rheumatology 24, 2314-2317.

Lechler R \& Warrens A (2000) HLA in Health and Disease, 2nd ed. London: Academic Press Ltd.

Le Drean E, Gervois N, Diez E, Semana G, Dreno B \& Jotreau F (1995) HLA class II-restricted recognition of common tumour epitopes on human melanoma cells by CD4+ melanomainfiltrating lymphocytes. European Journal of Immunology 25, 2732-2736.

Leek RD, Lewis CE, Whitehouse R, Greenall M, Clarke J \& Harris AL (1996) Association of macrophage infiltration with angiogenesis and prognosis in invasive breast carcinoma. Cancer Research 56, 4625-4629.

Lim S, Crawley E, Woo P \& Barnes PJ (1998) Haplotype associated with low interleukin-10 production in patients with severe asthma (letter). Lancet 352, 113.

McCarron SL, Edwards S, Evans PR, Gibbs R, Dearnaley DP, Dowe A, Southgate D, The CRC/BPG UK Familial Prostate Cancer Study Collaborators, Easton DF, Eeles RA \& Howell WM (2002) Influence of cytokine gene polymorphisms on the development of prostate cancer. Cancer Research 62, 3369-3372.

Maini RN \& Taylor PC (2000) Anti-cytokine therapy for rheumatoid arthritis. Annual Review of Medicine 51, 207-229.

Marshall SE, McLaren AJ, Haldar NA, Bunce M, Morris PJ \& Welsk KI (2000) The impact of recipient cytokine genotype on acute rejection after renal transplantation. Transplantation $\mathbf{7 0}$, $1485-1491$.

Mayser P, Mrowietz U, Arenberger P, Bartak P, Buchwald J, Christophers E, Jablonska S, Salmhofer W, Schill WB, Kramer HJ, Schlotzer E, Mayer K, Seeger W \& Grimminger F (1998) Omega-3 fatty acid-based lipid infusion in patients with chronic plaque psoriasis: results of a double-blind, randomized, placebocontrolled, multicenter trial. Journal of the American Academy of Dermatology 38, 539-547.

Messer G, Spengler U, Jung MC, Honold G, Blomer K, Pape GR, Riethmuller G \& Weiss EH (1991) Polymorphic structure of the tumor necrosis factor (TNF) locus: an NcoI polymorphism in the first intron of the human TNF- $\beta$ gene correlates with a variant amino acid in position 26 and a reduced level of TNF- $\beta$ production. Journal of Experimental Medicine 173, 209-219.

Mittal KK, Mickey MR, Singal DP \& Terasaki PI (1968) Serotyping for homotransplantation: refinement of microdroplet lymphocyte cytotoxicity test. Transplantation 6, 913-927.

Moffatt MF \& Cookson WO (1997) Tumour necrosis factor haplotypes and asthma. Human Molecular Genetics 6, 551-554.

Murch SH, Lamkin VA, Savage MO, Walker-Smith JA \& MacDonald TT (1991) Serum concentrations of tumour necrosis factor- $\alpha$ in childhood chronic inflammatory bowel disease. Gut 32, 913-917.

Nepom GT (2000) HLA and type I diabetes. In HLA in Health and Disease, 2nd ed., pp. 231-237 [R Lechler and A Warrens, editors]. London: Academic Press Ltd.

Nepom GT, Gersuk V \& Nepom BS (1996) Prognostic implications of HLA genotyping in the early assessment of patients with rheumatoid arthritis. Journal of Rheumatology 23, 5-9.

Olerup O \& Zetterquist H (1992) HLA-DR typing by PCR amplification with sequence-specific primers (PCR-SSP) in 2 
hours: An alternative to serological DR typing in clinical practice including donor-recipient matching in cadaveric transplantation. Tissue Antigens 39, 225-235.

Ollier W \& Thomson W (1992) Population genetics of rheumatoid arthritis. In Rheumatic Disease Clinics of North America, pp. 741-759 [GT Nepom, editor]. Philadelphia, PA: WB Saunders.

Perrey C, Pravica V, Sinnott PJ \& Hutchinson IV (1998) Genotyping for polymorphisms in interferon- $\gamma$, interleukin-10, transforming growth factor- $\beta 1$ and tumour necrosis factor- $\alpha$ genes: a technical report. Transplant Immunology 6, 193-197.

Poole KL, Gibbs PJ, Evans PR, Sadek SA \& Howell WM (2001) Influence of patient and donor cytokine genotypes on renal allograft rejection: evidence from a single study. Transplant Immunology 8, 259-265.

Robinson J, Waller MJ, Parham P, Bodmer JG \& Marsh SGE (2001) IMGT/HLA Database - a sequence database for the human major histocompatibility complex. Nucleic Acids Research 29, 210-213.

Ross J (2000) Sequencing-based typing. In Histocompatibility Testing, pp. 213-246 [J Bidwell and C Navarrete, editors]. London: Imperial College Press.

Ross R (1993) The pathogenesis of atherosclerosis: a perspective for the 1990s. Nature 362, 801-809.

Sankaran D, Ashraf S, Martin S, Roberts I, Short C, Dyer PA, Sinnott PJ \& Hutchinson IV (1998) High interleukin 10 producer genotype is not protective against renal allograft rejection in high TNF $\alpha$ producers. European Journal of Immunogenetics 25, 68.

Schulman CC, Ekane S \& Zlotta AR (2001) Nutrition and prostate cancer: evidence or suspicion? Urology 58, 318-334.

Scott H, Nilsen E, Sollid LM, Lundin KE, Rugtveit J, Molberg O, Thorsby E \& Brandtzaeg P (1997) Immunopathology of gluten-sensitive enteropathy. Springer Seminars in Immunopathology 18, 535-553.

Sollid LM, Spurkland A \& Thorsby E (2000) HLA and gastrointestinal diseases. In HLA in Health and Disease, 2nd ed., pp. 249-262 [R Lechler and A Warrens, editors]. London: Academic Press Limited.
Sollid LM \& Thorsby E (1993) HLA susceptibility genes in celiac disease: genetic mapping and role in pathogenesis. Gastroenterology 105, 910-922.

Sorrentino R \& Tosi R (1997) HLA-B27 subtypes: ankylosing spondylitis association versus peptide binding specificity. In HLA-B27 in the Development of Spondyloarthropathies, pp. 135-144 [C López-Larrea, editor]. Heidelberg: Springer.

Taylor GM, Dearden S, Payne N, Ayres M, Gokhale DA, Birch JM, Blair V, Stevens RF, Will AM \& Eden OB (1998) Evidence that an HLA-DQA1-DQB1 haplotype influences susceptibility to childhood common acute lymphoblastic leukaemia in boys provides further support for an infection-related aetiology. British Journal of Cancer 78, 561-565.

Thorsby E (1997) Invited anniversary review: HLA associated diseases. Human Immunology 53, 1-11.

Turner D, Grant S, Yonan N, Sheldon S, Dyer PA, Sinnott PJ \& Hutchinson IV (1997a) Cytokine gene polymorphism and heart transplant rejection. Transplantation 64, 776-779.

Turner DM, Williams DM, Sankaran D, Lazarus M, Sinnott PJ \& Hutchinson IV (1997b) An investigation of polymorphism in the interleukin-10 gene promoter. European Journal of Immunogenetics 24, 1-8.

Uryu N, Maeda M, Ota M, Tsuji K \& Inoko H (1990) A simple and rapid method for HLA-DRB and -DQB typing by digestion of PCR-amplified DNA with allele specific restriction endonucleases. Tissue Antigens 35, 20-31.

van der Poll T \& van Deventer SJ (1999) Cytokines and anticytokines in the pathogenesis of sepsis. Infectious Disease Clinics of North America 13, 413-426.

Vesalainen S, Lipponen R, Talja M \& Syrjanen K (1994) Histological grade, perineural infiltration, tumour infiltrating lymphocytes and apoptosis as determinants of long-term prognosis in prostatic adenocarcinoma. European Journal of Cancer 30A, 1797-1803.

Westendorp RG, Langermans JAM, Huizinga TW, Verweij CL \& Sturk A (1997) Genetic influence on cytokine production and fatal meningococcal disease. Lancet 349, 170-173.

Ye S, Dillon S, Ke X, Collins AR \& Day INM (2001) An efficient procedure for genotyping single nucleotide polymorphisms. Nucleic Acids Research 29, e88. 